\title{
Small Business Innovation in Russian Universities
}

\author{
Kaspina R.G. \\ Yerina T.V.
}

Kazan Federal University, Institute of Management, Economics and Finance, Kazan, 420008, Russia

\section{Doi:10.5901/mjss.2014.v5n24p227}

\begin{abstract}
This article describes the problems of small innovative businesses, established in universities. Based on the analysis of the legal framework, the study of small innovative enterprises identified and critically evaluated the practical problems of compliance with the legislation, the purpose of their creation in relation to economic activities. The directions of development improve the efficiency of their operation. The study based on the survey of leading Russian Universities and the number of the most efficient small innovative enterprises operating today.
\end{abstract}

Keywords: University scientific educational institution, a small investment company, investment, business

\section{Introduction}

Innovative potential of high school traditionally assessed at a high level: an intellectual cadres, material and technical base, the ability to organize and carry out serious research, international connections. Legally it is possible for schools to create their own business entities applying results of intellectual activity, the exclusive rights to which belong to these institutions. Thus, the Russian government planned to create an "innovation zone" around Russia's state institutions of science and higher education. However, as the study shows that only a third of the established organizations really works, a third exists only on paper, and the rest - are in an intermediate state.

\section{Methods}

According to the Federal Law dd. 22.08.1996 N 125-FZ "Concerning Higher and Postgraduate Vocational Education" the main target of developments is to provide real implementation of scientific and technological activity's results in production which are created at cost of budget money. [1.2] According to the Law budgetary scientific establishments, scientific establishments of national science academies, state funded educational institutions of higher professional education, higher vocational education institutions of national science academies (hereafter referred to as scientific and educational institutions) are authorized to create business entities without the consent of property owner. [3]Nevertheless, disposal of interests (shares) in equity capitals of these business entities can be performed only with advanced consent of relevant holders. It is set forth in the Law that scientific and educational institutions are responsible for notifying federal executive authority, which carries out functions involving formulation of State police and normative legal regulation in regard to scientific and scientific and technological activities (Federal Educational Agency of Russia) when creating this kind of institution. [4.5] Notification of the fact that this institution has been created has to be directed to the Agency during 7 days from the moment of its legal registration. Also there should be information sent to this legal body about including the newly created institution to Uniform State Register of Legal Entities. Business entities can be created as limited liability company or joint company. Scientific and educational institutions can create business entities solely or with the involvement of others as founders. The share of scientific and educational institutions in the equity capital of the business entities that they create has to be more than $25 \%$ (for joint companies) and more than $1 / 3$ (for limited liability corporations). Interest (share) of others participating in the equity capital of business entity has to be paid with money not less than in half. [7]The Law has it that business entity does not lose its status of small business entity regardless of share that scientific and educational institutions have in its equity capital. Herewith its activity has to consist of practical usage (implementation) of results of intellectual activity and exclusive rights on these results belong to founders (participants) - scientific and educational entities. Scientific and educational entities can bring rights to use results of intellectual activity according to license agreements to equity capitals of business entities. Herewith exclusive rights on 
intellectual activity's results are beyond alienation according to the second paragraph of the first part of the article 1233 of Civil Code of Russian Federation. Also scientific and educational institutions can bring into equity capital of business entities the money, equipment and other property which are under operational management of enterprises in manner required by Code of Russian Federation. Equity capital formation order for joint company and limited liability company is regulated by the articles 90, 99-101 of Civil Code of Russian Federation, chapter 3 of Federal Law dd. $8^{\text {th }}$ of February 1998 № 14-Ф3 «Concerning Limited Liability Companies» and chapter 3 of Federal Law dd. 26 ${ }^{\text {th }}$ of December 1995 № 208- $\$ 3$ «Concerning Joint Companies». Scientific and educational institutions perform management of interests (shares) in equity capital of business entities as participants according to order set by civil legislation. In this case the Law sets restriction to disposal of interests (shares) in business entities' equity capital. $[8,9,10]$ Thus, alienation (disposal) of interests (shares) belonging to scientific and educational institutions in business entities created with their participation is allowed only with advanced consent of property owner of these entities [11,12]. This restriction refers only to contributions to equity capital as to rights to use results of intellectual activity with license agreements and money, equipment and other property

\section{Discussions}

So despite scientific and educational institutes transfer objects of state property which are under their operational management, in return the state receives the ownership of interest (share unit) in equity capital of created business entities. Also the Law regulates that earnings from disposal of interests (shares) in equity capitals of business entities as well as share of profits of business entities received by scientific and educational institutions pass to their individual disposal and go only to legal protection of intellectual activity's results, remuneration payment to their authors and performing statutory activities of these entities.[13,14] In the table 1 there is an overview of small innovative enterprises (SIE) number in a range of top higher education institutes of Russia.

Table 1. Number of small innovative enterprises of top Universities of Russia

\begin{tabular}{|c|l|c|}
\hline № & Name of University & Number of SIE, units. \\
\hline 1 & Tomsk State University of Control Systems and Radioelectronics & 120 \\
\hline 2 & Belgorod State Technological University named after V.G. Shukhov & 67 \\
\hline 3 & Kazan Federal University & 39 \\
\hline 4 & Lomonosov Moscow State University & 38 \\
\hline 5 & Kazan National Research Technical University named after A.N.Tupolev - KAl (KNRTU-KAI) & 23 \\
\hline 6 & Saint-Petersburg Electrotechnical University "LETI" & 14 \\
\hline 7 & Tambov State University & 14 \\
\hline 8 & Michurinsk State Agrarian University & 12 \\
\hline 9 & N.P.Ogarev Mordovia State University & 10 \\
\hline 10 & Kazan State University of Architecture and Engineering & 10 \\
\hline 11 & Tambov State Technical University & 9 \\
\hline
\end{tabular}

Distribution of small innovative enterprises by sectors shows in Table 2, according to the table have the highest economic priority enterprises operating in the chemical and petrochemical industry as well as technology transfer.

Table 2. Functioning of small innovative enterprises (SIE) by sectors

\begin{tabular}{|l|c|c|c|c|}
\hline \multirow{2}{*}{ Sectors } & \multicolumn{4}{|c|}{ Functioning SIE, \% } \\
\cline { 2 - 6 } & 2010 & 2011 & 2012 & 2013 \\
\hline Management, marketing, business planning & 9,09 & 0,0 & 20 & 7,14 \\
\hline Chemicals, Petrochemicals & 36,36 & 13,6 & 10 & 21,43 \\
\hline Information Technology & 4,55 & 4,5 & 20 & 7,14 \\
\hline Medicine and Biology & 4,55 & 31,8 & 10 & 14,29 \\
\hline Physics, mechanics, measuring and control devices and systems & 9,09 & 18,2 & 10 & 7,14 \\
\hline Others, including the transfer of technologies & 36,36 & 31,8 & 30 & 42,86 \\
\hline Total & 100 & 100 & 100 & 100 \\
\hline
\end{tabular}


Currently in Russia there is a range of restrictions which prevent small innovative enterprises from developing and effective functioning.

\section{Results}

Upon that analysis of regulations of the Law has the following main practical problems occurring during its implementation. All those of problems is divided in two main groups. The first group of problems is connected with creation of small businesses the equity capital of which contains results of intellectual activity. The second group of problems is connected with entities which equity capitals contain rights to use tangible assets.

The first and the main problem is to show what privatization of scientific assets gives to various groups of participants and above all to managers of higher institutes and other state funded organizations. It is quite difficult to apply the Law and it requires certain expenses even before investor is found. Currently state funded organization is more attracted to signing an economic contract as a part of funding source other than the public purse than to bear additional expenses for organizing and managing independent entity further on. This happens due to specificity of budget regulations of Russia according to which state funded organizations do not have free money and can spend financial resources only on purposes defined by budget financing targets.[17]

The second problem occurs when trying to bring existing developments to shape applicable to including it into created small businesses. The main point is to enter results of intellectual activity in the company's book minimizing emerging income tax. Expenses of creation are already written off and the appeared asset falls under taxation. [18]

The third problem is to find an investor. In order to find an investor, it is necessary to improve results of intellectual activity so that they reach the condition of innovative project, make calculation and define what share state funded organization wants to receive in a created small business. Apart from that this information has to be given to investor. This work requires certain expenses which state funded organizations will bear. [19]

The forth problem is transfer of non-exclusive rights to exclusive rights. Investor is very careful with non-exclusive rights. At the same time legislator gave an opportunity for state funded organizations to bring only non-exclusive rights into small business. Thus one of the targets of small business which will be created is to transfer non-exclusive rights into exclusive. [20]

Among ways of solving these problems presence of special department can be recommended, but it is better to have individual legal entity which organizes work starting from commercially perspective results of intellectual activity and ending with certain control of work of already created small businesses.[21]

The presence of investor depends on the target of creating small businesses and what assets are put into them. There are five main targets. The first target is to legalize current business. There are enterprises which produce products basing on technologies developed in state funded organizations. Before the law 217- $\$ 3$ was adapted it had been illegal. Now there is a possibility to legalize this situation. Here the state funded organization and investor already exist in principle.[22]

The second target is privatization of tangible assets which are already being used to manage business and bring profit due to incomes from budgetary sources. For instance, production of state funded organization which has experience and which is in demand. Transfer of corresponding assets into small business makes it investment-attractive which is beneficial both for organizers of this business and for state fund organizations.

The third target is to privatize assets with the help of which it is possible to create small business within a short time. Most likely this is various repair shops, information database maintenance etc.

The forth target is to redistribute financial flows of state funded organizations, receive additional grants etc. Small businesses are created by state funded organization and investor; however, they will have state money as main financial source. Most likely maximum in one year initial investor will siphon off funds invested firstly and small business will carry on working. This is exactly the way to encourage most valuable employees, perform small applied research etc., which is now difficult to do because of existing budget financing targets.

\section{Conclusions}

The analysis of small innovative enterprises universities led to the following conclusions and recommendations to improve the functioning.

Small businesses are the budgetary institutions and investors, however, as the main source of finance are public funds. Most likely, a maximum of one year initial investor will lead initially invested funds, and small business will continue to operate. It is thus possible to encourage the most valuable employees, perform small applied research that is now 
quite difficult to make due to the existing budget revenue and expenditure.

Outlined options will allow expanding application of mechanism of innovative entrepreneurship in the sphere of higher school, to create additional working places, to improve investment climate in Russian Federation.

\section{References}

Federal Law of 22.08.1996 N 125-FZ "On Higher and Postgraduate Professional Education"

Federal Law of 02.08.2009 N 217-FZ "On Amendments to Certain Legislative Acts of the Russian Federation on the establishment of the budget scientific and educational institutions of business entities for the purpose of practical application (implementation) of the results of intellectual activity"

RF Government Resolution of 18 December 1995 N 1256 "On the Federal program of state support of small business in the Russian Federation for 1996 - 1997" (with amendments)

Order of the Ministry of Industry and Trade of the Russian Federation of February 15, 2010 N 123 "On approval of the departmental target program" Development of small and medium enterprises in the fields of industry and trade "

Recommendations for the development of innovative development programs of joint-stock companies with state participation, public corporations and the federal state unitary enterprise (approved. Decision of the Government Commission on High Technology and Innovation August 3, 2010, protocol N 4)

Resolution of the Government of the Russian Federation of December 31, 1999 N 1460 "On the complex of measures for the development and state support of small enterprises in the sphere of material production and to facilitate their innovation"

RT Law of April 22, 2011 N 13-LRT "On Approval of the Socio-Economic Development of the Republic of Tatarstan for 2011-2015" (with amendments)

Order of the Ministry of Culture of the Russian Federation of July 21, 2010 N 408 "On approval of the methodology for assessing the impact of the research organizations under the jurisdiction of the Ministry of Culture of the Russian Federation, performing research, development and technological works of civil purpose"

Order of the Ministry of Sport, Tourism and Youth Policy of the Russian Federation of July 16, 2010 N 730 "On approval of the Methodology for assessing the effectiveness of scientific organizations under the jurisdiction of the Ministry of Sport, Tourism and Youth Policy of the Russian Federation, performing research, development and engineering civilian work "

Ministry of Education and Science of the Russian Federation dated July 7, $2010 \mathrm{~N} 754$ "On approval of the competition for the selection of programs for the development of innovation infrastructure, including support for small innovative businesses, federal educational institutions of higher education"

Order of the Ministry of Russia June 25, 2010 N 219 "On approval of the Methodology for assessing the effectiveness of scientific organizations, subordinated to the Ministry of Natural Resources and Ecology of the Russian Federation, performing research, development and technological works of civil purpose"

Order of the Federal Service for Supervision in Education and Science, June 25, 2010 N 1756 "On Approval of the Methodology for assessing the effectiveness of scientific organizations, performing research, development and technological works civil purposes, subordinated to the Federal Service for Supervision in Education and Science "

Kaspina, R.G. and L.A. Plotnikova, 2014. Accounting of external economic activity of Russian companies: Experience and difficulties. Life Science Journal, 11 (11): 108-111.

Kaspina, R.G., L. S. Khapugina and E. A. Zakirov, 2014. Employment of activity-based costing in the process of company business model generation. Life Science Journal, 11 (8): 356-359.

Shigaev A.I. Operating characteristics of high performance companies: strategic direction for management / A.I. Shigaev, B.E. Needles, M. Powers, M.L. Frigo // Performance Measurement and Management Control: Behavioral Implications and Human Actions. Studies in Managerial and Financial Accounting, Volume 28. Edited by: Antonio Davila, Marc J. Epstein, Jean-François Manzoni. - Emerald Group Publishing Limited, 2014. - p. 25-51.

Shigaev A.I. Strategy and integrated financial ratio performance measures: A longitudinal multi-country study of high performance companies / A.I. Shigaev, B.E. Needles, M. Powers, M.L. Frigo // Performance Measurement and Management Control: Innovative Concepts and Practices. Studies in Managerial and Financial Accounting, Volume 20. Edited by: Marc J. Epstein, Jean-François Manzoni, Antonio Davila. - Emerald Group Publishing Limited, 2010. - p. 211-252.

Perruci, G., 2014. Leadership Education Across Disciplines: The Social Science Perspective, Journal of Leadership Studies, 7(4):43-47.

Buschlen, E andK. L. Guthrie, 2014. Seamless Leadership Learning in Curricular and Cocurricular Facets of University Life: A Pragmatic Approach to Praxis, Journal of Leadership Studies, 7 (4) 58-64.

Akli, L., S. L. Moore, L. I. Rivera and P. J. Teller, 2014. Training, education, and outreach - Raising the bar, Concurrency Computation Practice and Experience, 26 (13): 2336-2343.

Wang, Q. and N. C. Liu, 2014. Higher education research institutes in Chinese universities, Studies in Higher Education.

Yudkevich, M., 2014. The Russian University: recovery and rehabilitation, Studies in Higher Education.

Markaryan, S.E., T. A. Snetkova and D. V. Khairullina, 2014. Administrative aspects of accounting organization. Russian experience and problems. Life Science Journal, 11(8): 107-111. 